\title{
Microstructure and Mechanical Properties of the Ductile Al-Ti-Mo-Nb-V Refractory High Entropy Alloys
}

\author{
GRZEGORZ CIEŚLAK, JULIUSZ DĄBROWA, MONIKA JAWAŃSKA, \\ AGNIESZKA PARZUCHOWSKA, and DARIUSZ OLESZAK
}

\begin{abstract}
A number of non-equimolar refractory high entropy alloys (RF HEAs) from the $\mathrm{Al}-\mathrm{Ti}-\mathrm{Mo}-\mathrm{Nb}-\mathrm{V}$ system are synthesized, with the selected compositions aimed to balance the conflicting requirements of the low-temperature ductility and high-temperature corrosion protection. Based on the thermodynamic modeling and experimental results, all the obtained alloys are characterized by the single-phase B2 structure with $\mathrm{V}$ acting as the main phase stabilizer. The microstructure and mechanical properties appear to be controlled mainly by the $\mathrm{Al}$ content, which is especially visible on the example of hardness, with a maximum value of 545 $\mathrm{HV}$ for $\mathrm{Al}_{20} \mathrm{Ti}_{5} \mathrm{Mo}_{25} \mathrm{Nb}_{25} \mathrm{~V}_{25}$ composition. For the selected $\mathrm{Al}_{20} \mathrm{Ti}_{5} \mathrm{Mo}_{25} \mathrm{Nb}_{25} \mathrm{~V}_{25}$ and $\mathrm{Al}_{10} \mathrm{Ti}_{30} \mathrm{Mo}_{20} \mathrm{Nb}_{20} \mathrm{~V}_{20}$ alloys, the measured stress-strain curves indicate the highly coveted, ductile room temperature behavior, with the values of ultimate strain measured under compression mode being 9.17 and 9.00 pct, respectively, and compressive fracture strain of 13.38 and 13.25 pct, respectively. The obtained results suggest that it is possible to include $\mathrm{Al}$ as a vital component of refractory HEAs without compromising their low-temperature ductility. The next intended step will be the characterization of the high-temperature corrosion behavior in order to investigate the potential selective oxidation capabilities of such materials.
\end{abstract}

https://doi.org/10.1007/s11661-021-06543-8

(C) The Author(s) 2021

\section{INTRODUCTION}

THE high entropy alloys-HEA's are currently one of the most intensively explored directions of studies in materials engineering. The possibility of obtaining such materials was for the first time investigated by Yeh and Huang in $1995,{ }^{[1]}$ however it was not until 2004 , when this concept was presented to the worldwide public for the first time..$^{[2,3]}$ Within the same timeframe, the original definition of high entropy materials was created, which still remains by far the most popular one. It defines high entropy alloys as alloys with five or more principal elements, with each element having a concentration ranging between 5 and 35 at. pct. Such composition enables achieving very high values of configurational entropy, which is maximized in the solid solution structure, consequently stabilizing these phases

GRZEGORZ CIEŚLAK, AGNIESZKA PARZUCHOWSKA, and DARIUSZ OLESZAK are with the Faculty of Materials Science and Engineering, Warsaw University of Technology, Wołoska str. 141, 02-507 Warsaw, Poland. Contact e-mail: grzegorz.cieslak@pw.edu.pl JULIUSZ DABROWA and MONIKA JAWAŃSKA are with the Faculty of Materials Science and Ceramics, AGH University of Science and Technology, Mickiewicza av. 30, 30059 Cracow, Poland.

Manuscript submitted August 6, 2021; accepted November 8, 2021.

Article published online November 26, 2021 over the intermetallic ones. For years, HEAs were believed to possess a number of extraordinary properties, initially categorized into the so-called "four core effects". ${ }^{[4]}$ Despite the fact that our view on their existence has greatly evolved during the last few years, ${ }^{[5,6]}$ it cannot be argued that the high entropy approach to materials design has greatly expanded the compositional space available for obtaining highly functional materials for a wide variety of applications. In the case of high entropy alloys, by far the most prospective application are the high-temperature structural materials. ${ }^{[5,7]}$ Multiple studies indicate that the mechanical properties of transition metal-based HEAs are comparable, or even superior to the ones of state-of-the-art Ni-based superalloys ${ }^{[3,8]}$ while offering a possibility of tailoring other properties, such as density, in a much more extensive way. Thanks to these exceptional properties, high entropy alloys are nowadays considered potential materials for energy, automotive, aerospace, and nuclear industries. ${ }^{[7,9]}$

While the development of HEAs started with the transition metal-based alloys, during the last decade another group of HEAs has gathered ever-increasing attention, namely the refractory metal-based high entropy alloys (RF HEAs). Initially developed by Senkov et al. ${ }^{[10]}$ in 2010 , over the years they have 
proved to possess an outstanding potential as the next-generation, high-temperature materials, in many cases displaying properties outclassing the conventional superalloys. $^{[5,11]}$ It is especially visible in terms of their high-temperature strength-while typical superalloys such as Inconel 718 or MAR-M 247 start displaying the drop-off of mechanical strength at temperatures exceeding $750{ }^{\circ} \mathrm{C}$, in the case of RF HEAs the onset of such behavior may start even $300{ }^{\circ} \mathrm{C}$ higher (e.g., the $\left.\mathrm{AlMo}_{0.5} \mathrm{NbTa}_{0.5} \mathrm{TiZr}^{[12]}\right)$ making them potential candidates to replace superalloys in some of the most demanding environments, such as aircraft engines. However, such an outstanding performance comes at a certain price, as despite the listed advantages, the RF HEAs also display a number of flaws, which currently disqualify them from actual applications. The two by far most severe are extremely poor oxidation resistance and insufficient low-temperature ductility of these alloys. The example here may be the results for the $\mathrm{Ta}_{20} \mathrm{Nb}_{20} \mathrm{~W}_{20} \mathrm{Mo}_{20} \mathrm{~V}_{20}$ and $\mathrm{Nb}_{25} \mathrm{Mo}_{25} \mathrm{Ta}_{25} \mathrm{~W}_{25}$ alloys, which were investigated by Senkov et al. in terms of their compressive strength. ${ }^{[13]}$ For the latter composition, the yield point at room temperature was determined to be $1246 \mathrm{MPa}$, with a compressive strength of $1270 \mathrm{MPa}$, which can be considered excellent performance. On the other hand, destruction of this material occurred at a deformation of $\varepsilon=1.7$ pct. As revealed by numerous further studies, ${ }^{[11]}$ such behavior appears to be typical for most of the RF HEAs, greatly limiting their prospects. Consequently, multiple studies dedicated to solving this problem have been conducted, which resulted in the formulation of the two most common approaches. The first one concentrates on the multiphase systems, where optimization of the interface morphology between phases (most commonly BCC/B2) allows increase of the low-temperature ductility ${ }^{[14]}$ The second approach was proposed by Sheikh et al. ${ }^{[15]}$ who observed increasing plasticity in RF HEAs containing IV group pure elements ( $\mathrm{Ti}, \mathrm{Hf}, \mathrm{Zr}$ ), which can be correlated with the decreasing value of the valence electron concentration $(V E C)$ parameter. ${ }^{[16]}$ The example of the alloy utilizing this principle can be the $\mathrm{Ta}_{20} \mathrm{Nb}_{20} \mathrm{Hf}_{20} \mathrm{Zr}_{20} \mathrm{Ti}_{20} \mathrm{HEA}$, ${ }^{[17]}$ which exhibited superior ductility behavior during compression tests with the yield point of about $929 \mathrm{MPa}$ at the maximum strain $\varepsilon$ $=50$ pct.

In terms of the oxidation resistance, the RF HEAs are a significant challenge, where no general answer can be given. ${ }^{[18]}$ Firstly, many of the refractory elements, e.g., $\mathrm{Mo}, \mathrm{V}$ or $\mathrm{Nb}$, oxidize forming highly volatile compounds. Secondly, most of the refractory elements form highly stable oxide phases, with the free energy of oxide formation being comparable or exceeding those of the typical, protective scales, i.e., $\mathrm{Cr}_{2} \mathrm{O}_{3}$ and $\mathrm{Al}_{2} \mathrm{O}_{3}$. This is especially true in the case of the IV group elements oxides, where enthalpies of formation for $\mathrm{HfO}_{2}, \mathrm{ZrO}_{2}$, and $\mathrm{TiO}_{2}$ are $-909,-855$, and -708 (rutile) $\mathrm{kJ} / \mathrm{mole}$ $\mathrm{O}_{2}$, respectively, compared with $-853 \mathrm{~kJ} / \mathrm{mole} \mathrm{O}_{2}$ for $\mathrm{Al}_{2} \mathrm{O}_{3}$, and $-538 \mathrm{~kJ} /$ mole $\mathrm{O}_{2}$ for $\mathrm{Cr}_{2} \mathrm{O}_{3},{ }^{[19]}$ making the formation of a protective scale problematic. Considering the above-mentioned positive influence of IV group elements on the ductility, it can be easily seen how challenging it may be to find a balance between various aspects of RF HEAs performance.

In the present study, an attempt to balance the composition of the RF HEAs in terms of the often contradicting requirements of mechanical and corrosion behavior is made. Based on the typical empirical criteria of HEAs solid solution formation, thermodynamic calculations, as well as the above-described factors affecting the performance of these materials, the non-equimolar alloys of satisfactory low-temperature ductility behavior are obtained, with a chemical composition at least theoretically optimized toward the requirements of the high-temperature corrosion.

\section{MATERIALS AND METHODS}

The compositions investigated within the current study are listed in Table I.

The designed alloys can be divided into two groups, both of them being based around the common Mo-Nb-V core. The selection of these three elements was based on their excellent mutual solubility as well as moderate values of oxides' enthalpies of formation, when compared with, e.g., IV group elements. ${ }^{[19]}$ For the first group, the equimolar combination of $\mathrm{Mo}-\mathrm{Nb}-\mathrm{V}$ accounted for 75 at. pct, while for the second one- 60 at. pct. The rest of the system was filled up by Al and Ti, with the latter element being the only IV group element producing oxide less stable than $\mathrm{Al}_{2} \mathrm{O}_{3}$. The use of aluminum was justified by the requirements of the high-temperature corrosion resistance, as it is the only viable element with the capability to form a protective scale (not considering the possibility of the formation of complex, spinel, protective scales as in Reference 20), since the stability of $\mathrm{Cr}_{2} \mathrm{O}_{3}$ appears to be too low in relation to the oxide phases of refractory elements. Furthermore, the introduction of chromium may lead to the formation of brittle Laves phases in the alloy. ${ }^{[1]}$ Unfortunately, despite the low value of $\mathrm{VEC}_{\mathrm{Al}}=3$, the influence of $\mathrm{Al}$ on the low-temperature ductility appears to be unfavorable, ${ }^{[11]}$ therefore it remains to be seen whether a compromise between the ductility and corrosion resistance requirements can be achieved.

The feasibility of the proposed compositions was further tested using the thermodynamic modeling within the CALPHAD formalism (CALculation of PHAse Diagrams). ${ }^{[21]}$ The calculations were performed using the Thermo-Calc software equipped with the latest HEAs-dedicated thermodynamic database, namely TCHEA 4. ${ }^{[21]}$

All the alloys were produced by the arc-melting method under argon atmosphere, using high purity elements (Al-Alfa Aesar 99.999 pct purity, Ti-Sigma Aldrich 99.99 pct, Mo-Sigma Aldrich 99.8 pct, NbSigma Aldrich 99.9 pct, and V-Alfa Aesar 99.7 pct). In all cases, the obtained ingots were re-melted more than three times to homogenize the composition. All ingots were obtained in a form of round droplets, weighing around $15 \mathrm{~g}$. The microstructure of the as-cast alloys was examined by, both, optical and scanning electron microscopy (SEM). In both cases, the 
Nominal Compositions

Group I: $\mathrm{Mo}_{25} \mathrm{Nb}_{25} \mathrm{~V}_{25}$-Based Group II: $\mathrm{Mo}_{20} \mathrm{Nb}_{20} \mathrm{~V}_{20}$-Based

$\mathrm{Ti}_{25} \mathrm{Mo}_{25} \mathrm{Nb}_{25} \mathrm{~V}_{25}$

$\mathrm{Al}_{15} \mathrm{Ti}_{10} \mathrm{Mo}_{25} \mathrm{Nb}_{25} \mathrm{~V}_{25}$

$\mathrm{Al}_{10} \mathrm{Ti}_{30} \mathrm{Mo}_{20} \mathrm{Nb}_{20} \mathrm{~V}_{20}$

$\mathrm{Al}_{20} \mathrm{Ti}_{5} \mathrm{Mo}_{25} \mathrm{Nb}_{25} \mathrm{~V}_{25}$

$\mathrm{Al}_{15} \mathrm{Ti}_{25} \mathrm{Mo}_{20} \mathrm{Nb}_{20} \mathrm{~V}_{20}$

$\mathrm{Al}_{20} \mathrm{Ti}_{20} \mathrm{Mo}_{20} \mathrm{Nb}_{20} \mathrm{~V}_{20}$

investigated samples were ground and polished according to the standard metallographic procedures using $\mathrm{Al}_{2} \mathrm{O}_{3}$ lubricant. Optical observations were performed using Carl Zeiss Axiovert 40 MAT microscope on the samples previously etched using a mixture of $68 \mathrm{~cm}^{3}-$ $\mathrm{H}_{2} \mathrm{O}, 16 \mathrm{~cm}^{3}-\mathrm{HNO}_{3}$, and $16 \mathrm{~cm}^{3}-\mathrm{HF}$. Microstructure observations and chemical analysis were performed using a Hitachi S3500N scanning electron microscope equipped with an energy dispersive X-ray spectrometer (EDS). The structure of the alloys was studied using the $\mathrm{X}$-ray diffraction technique, using the Rigaku diffractometer (with $\mathrm{Cu}=1.5418 \AA$ radiation) operating within the 20 to $120 \mathrm{deg}$ range. The hardness tests were performed using the Zwick hardness tester, under an indentation load of $1 \mathrm{~kg}(9.81 \mathrm{~N})$. Five measurements were performed for each alloy. The compression tests were performed with a standard strain rate $1 \times 10^{-3} \mathrm{~s}^{-1}$, using the Zwick compression machine. For each investigated material, three samples were tested. The specimens were cut using the electrical discharge machining method (EDM). The dimensions of the samples were as follows: $1.5 \mathrm{~mm}$ in diameter and 4.5 in height.

\section{RESULTS AND DISCUSSION}

\section{A. Thermodynamic Modeling}

The plots presenting the temperature dependence of the phase fraction in investigated alloys calculated based on the TCHEA 4 database, are presented in Figure 1.

Considering the as-cast state of the alloys presented in this study, based on the results of thermodynamic modeling, it can be expected that the alloys should exhibit a single-phase structure, with the ordered body-centered cubic B2 phase being present in all cases. Still, the presence of additional phases may become possible in selected materials within the low- to medium temperature range. In the case of the $\mathrm{Mo}_{25} \mathrm{~N}$ $\mathrm{b}_{25} \mathrm{~V}_{25}$-based series, with the increasing amount of $\mathrm{Al}$, a tendency toward the formation of the $\mathrm{A} 15, \mathrm{Cr}_{3} \mathrm{Si}$-archetype phase can be noticed. On the other hand, in the case of the $\mathrm{Mo}_{20} \mathrm{Nb}_{20} \mathrm{~V}_{20}$-based series, the phase purity is preserved even in the $\mathrm{Al}_{15} \mathrm{Ti}_{25} \mathrm{Mo}_{20} \mathrm{Nb}_{20} \mathrm{~V}_{20}$ composition. Still, exceeding the 15 at. pct Al content threshold enables the formation of the secondary B2 phase (B2\#2), with its content being roughly equal to the one of the main $\mathrm{B} 2$ phase within the $600{ }^{\circ} \mathrm{C}$ to $1000{ }^{\circ} \mathrm{C}$. In general, the observed tendencies are not completely intuitive. For example, one can expect that due to the excellent solubility between $\mathrm{Mo}, \mathrm{Nb}$, and $\mathrm{V}$, the $\mathrm{Mo}_{25} \mathrm{~N}$ $\mathrm{b}_{25} \mathrm{~V}_{25}$-based series should exhibit a higher level of stability, which is not the case. Another interesting aspect is the formation of the $\mathrm{B} 2 \# 2$ phase in $\mathrm{Al}_{20} \mathrm{Ti}_{20}$ $\mathrm{Mo}_{20} \mathrm{Nb}_{20} \mathrm{~V}_{20}$, a phase non-existent in $\mathrm{Al}_{20} \mathrm{Ti}_{5-}$ $\mathrm{Mo}_{25} \mathrm{Nb}_{25} \mathrm{~V}_{25}$. In order to investigate the influence of specific elements on the phase formation behavior, the temperature-dependent elemental compositions of the two main phases in the $\mathrm{Al}_{15} \mathrm{Ti}_{10} \mathrm{Mo}_{25} \mathrm{Nb}_{25} \mathrm{~V}_{25}, \mathrm{Al}_{20} \mathrm{Ti}_{5-}$ $\mathrm{Mo}_{25} \mathrm{Nb}_{25} \mathrm{~V}_{25}$ and $\mathrm{Al}_{20} \mathrm{Ti}_{20} \mathrm{Mo}_{20} \mathrm{Nb}_{20} \mathrm{~V}_{20}$ alloys (the ones with the prominent low-temperature content of secondary phases), are presented in Figure 2.

As visible, in the case of the B2 phase (Figures 2(a), (c) and (e)), in all the considered alloys vanadium appears to be the strongest B2-former, with its content dominating this phase in the low-temperature region. On the other hand, vanadium does not take part in the formation of the A15 phase (Figures 2(b) and (d)), which is dominated by Mo. Such behavior can be considered surprising taking into account the excellent solubility of $\mathrm{V}$ with all other elements in the system $(\mathrm{Ti}$ included) except for Al. While both Mo and Nb appear to have equally complicated binary phase diagrams with $\mathrm{Al}$ as $\mathrm{V}$, with multiple intermetallic phases at low temperatures, neither of them segregates in a similar manner to vanadium. Regarding the B2\#2 phase (Figure 2(f)), it is clear that its presence results from the high content of $\mathrm{Ti}$, the main component, explaining the lack of such phase in $\mathrm{Al}_{20} \mathrm{Ti}_{5} \mathrm{Mo}_{25} \mathrm{Nb}_{25} \mathrm{~V}_{25}$ (Figure 1(c)). Again, the solubility of vanadium is limited in the secondary phase, this time, however, it increases with the increasing temperature, until the primary B2 phase consumes the B2\#2.

Simultaneously with the computer simulation process, the most typical empirical criteria were also considered, ${ }^{[22]}$ i.e., configurational entropy $\left(\Delta H_{\text {mix }}\right)$ and mixing enthalpy $\left(\Delta S_{\text {mix }}\right), \delta$ parameter (effective atomic size mismatch), $\Omega$ parameter (entropy-enthalpy ratio at melting temperature), and valence electron concentration VEC. The calculated values for the considered alloys are presented in Table II.

As one can see, the results of the thermodynamic modeling are in good agreement with the expectations based on the empirical criteria. In all cases, the obtained values are within the limits typical for the body-centered cubic, single-phase structures. ${ }^{[9]}$ It is worth noting that the discussed negative influence of $\mathrm{Al}$ on the phase stability is also reflected in this simplified analysis, as all the alloys determined to be susceptible to secondary phase precipitation are characterized by the lowest values of $\Omega$ parameter. 


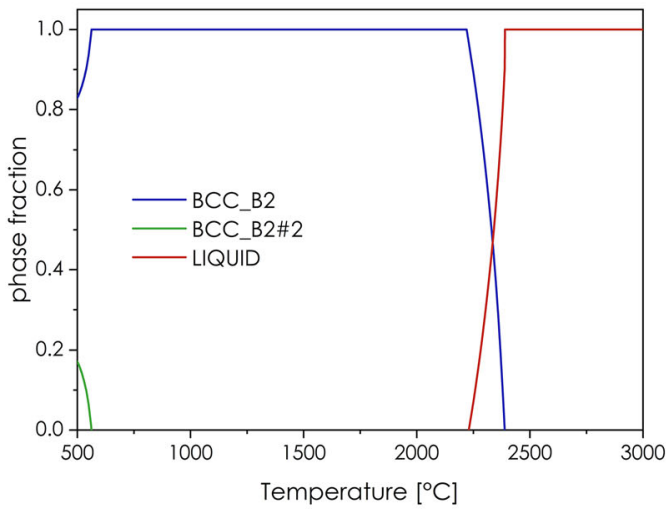

(a)

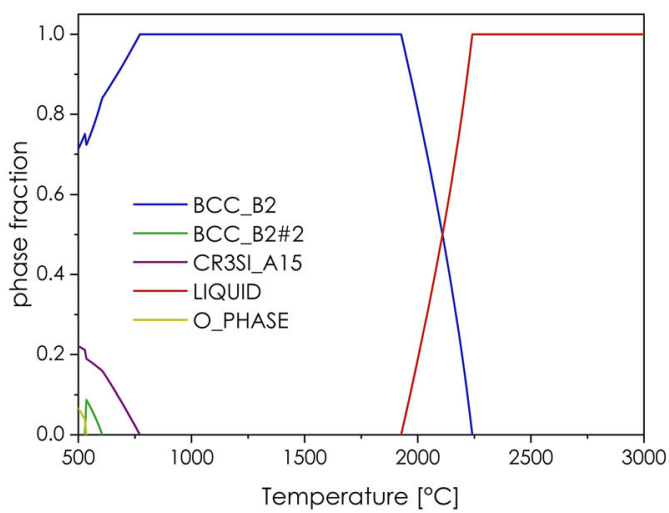

(c)

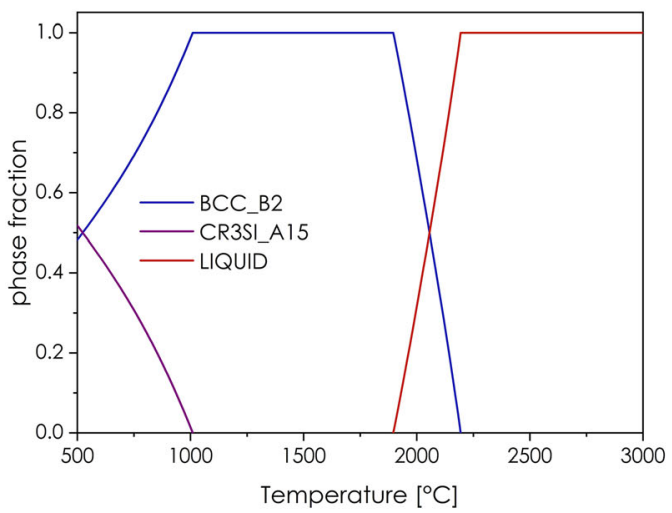

(e)

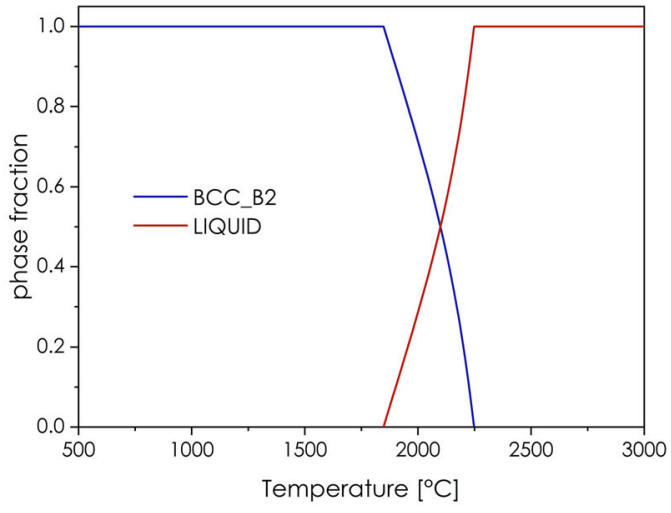

(b)

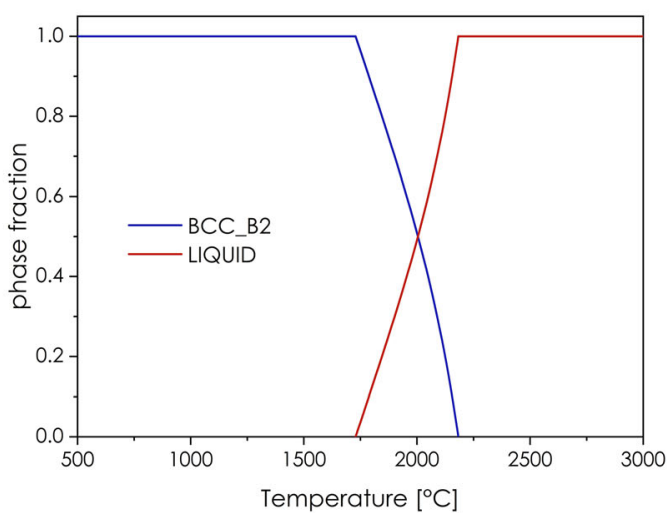

(d)

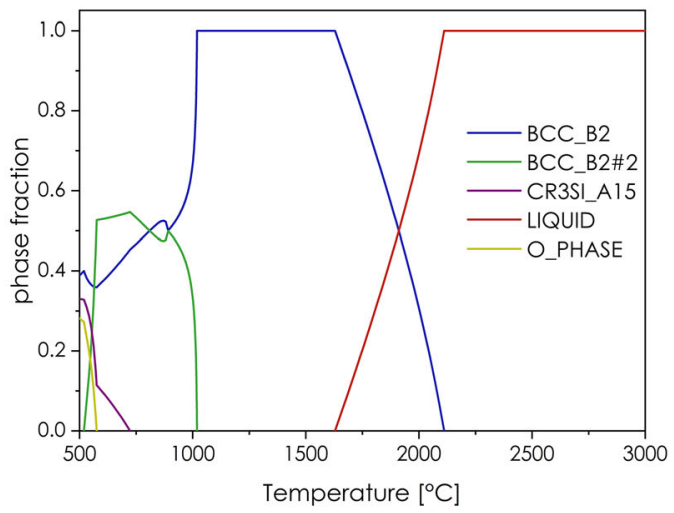

(f)

Fig. 1-Temperature dependence of phase fraction in: (a) $\mathrm{Ti}_{25} \mathrm{Mo}_{25} \mathrm{Nb}_{25} \mathrm{~V}_{25} ; \quad$ (b) $\mathrm{Al}_{15} \mathrm{Ti}_{10} \mathrm{Mo}_{25} \mathrm{Nb}_{25} \mathrm{~V}_{25} ; \quad$ (c) $\mathrm{Al}_{20} \mathrm{Ti}_{5} \mathrm{Mo}_{25} \mathrm{Nb}_{25} \mathrm{~V}_{25} ; \quad$ (d) $\mathrm{Al}_{10} \mathrm{Ti}_{30} \mathrm{Mo}_{20} \mathrm{Nb}_{20} \mathrm{~V}_{20}$; (e) $\mathrm{Al}_{15} \mathrm{Ti}_{25} \mathrm{Mo}_{20} \mathrm{Nb}_{20} \mathrm{~V}_{20} ;(f) \mathrm{Al}_{20} \mathrm{Ti}_{20} \mathrm{Mo}_{20} \mathrm{Nb}_{20} \mathrm{~V}_{20}$.

\section{B. Materials Characterization}

The XRD diffractograms of the investigated alloys are presented in Figure 3. In all cases the main observed structure was the BCC (body-centered cubic) one, which is in agreement with the results of thermodynamic modeling, as well as the results for the $\mathrm{Al}_{x} \mathrm{MoNbTiV}$ alloys studied by Chen et al. ${ }^{[23]}$ However, as indicated by the above-presented results of thermodynamic modeling, it appears that the observed structure should be classified as the ordered B2 variant of the BCC structure, rather than previously reported disordered
A2. The B2 lattice parameters, determined using the Riley-Nelson method, are presented in Table III. It is worth noting that in the case of the $\mathrm{Ti}_{25} \mathrm{Mo}_{25} \mathrm{Nb}_{25} \mathrm{~V}_{25}$ and $\mathrm{Al}_{20} \mathrm{Ti}_{20} \mathrm{Mo}_{20} \mathrm{Nb}_{20} \mathrm{~V}_{20}$ alloys, for which literature data is available, the lattice parameters turned out to be slightly lower than previously reported..$^{[23]}$

The results of the optical observations of the etched samples are presented in Figure 4.

As one can see, the microstructures of alloys (Figures 4(a) to (f)) consist of equiaxed grains. For the $\mathrm{Mo}_{25} \mathrm{Nb}_{25} \mathrm{~V}_{25}$-based series (Figures 4(a) to (c)), with the growing $\mathrm{Al}$ content, the grains size is also increasing 


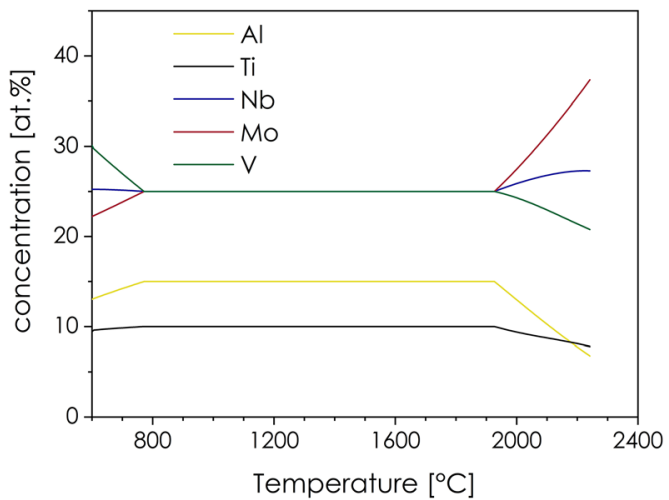

(a)

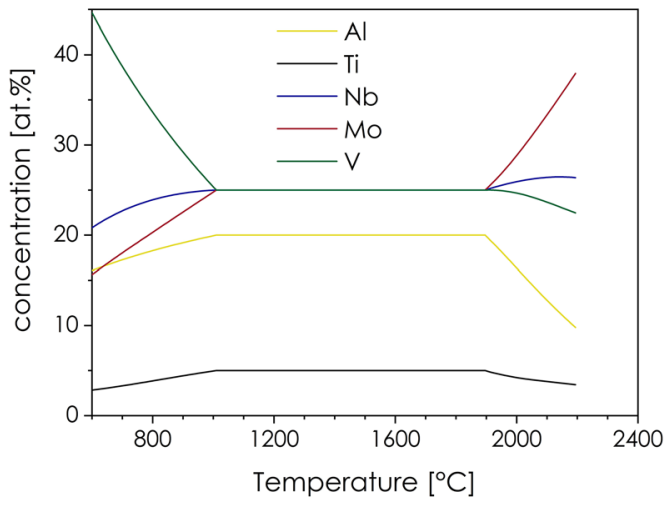

(c)

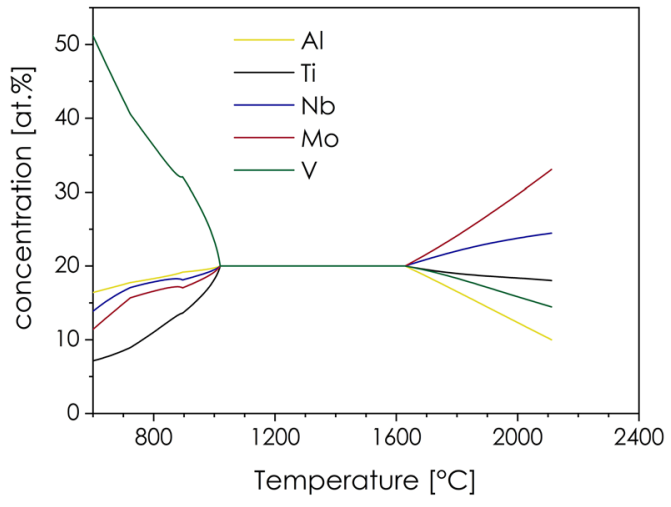

(e)

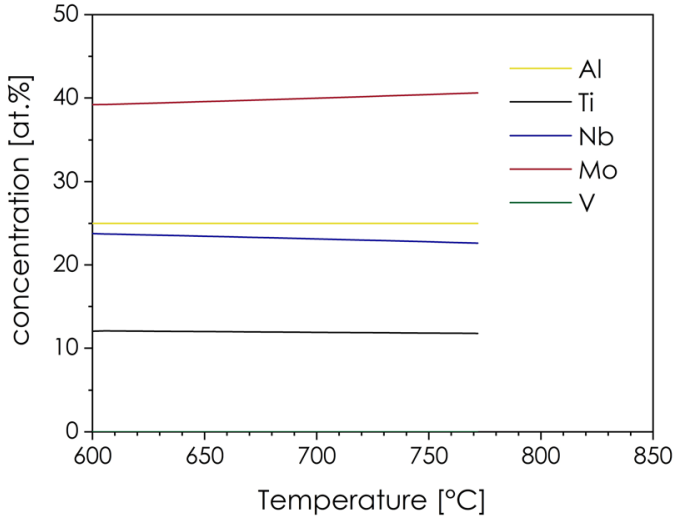

(b)

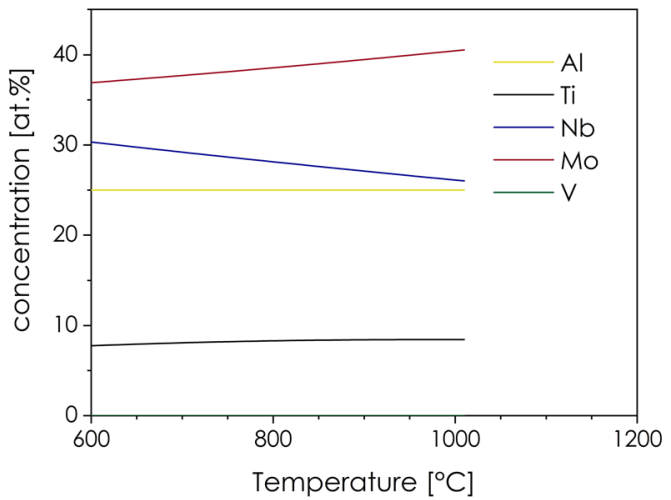

(d)

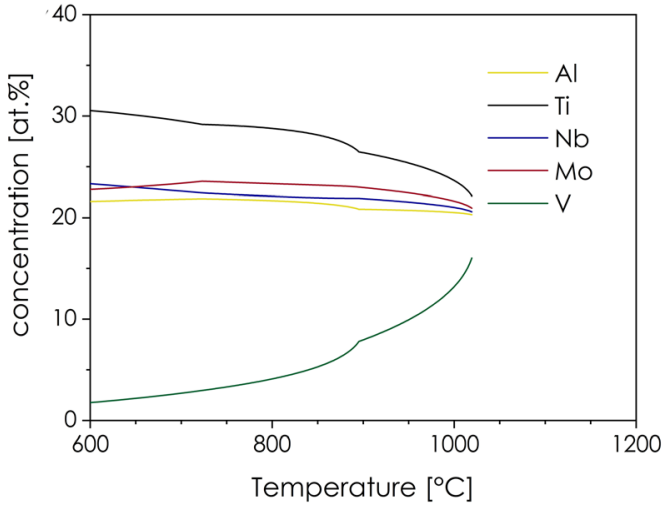

(f)

Fig. 2-Temperature-dependent compositions of the main phases: (a) B2 phase in $\mathrm{Al}_{15} \mathrm{Ti}_{10} \mathrm{Mo}_{25} \mathrm{Nb}_{25} \mathrm{~V}_{25} ;\left(\right.$ b) $\mathrm{Al}_{15}$ phase in $\mathrm{Al}_{15} \mathrm{Ti}_{10} \mathrm{Mo}_{25} \mathrm{Nb}_{25} \mathrm{~V}_{25}$; (c) B2 phase in $\mathrm{Al}_{20} \mathrm{Ti}_{5} \mathrm{Mo}_{25} \mathrm{Nb}_{25} \mathrm{~V}_{25}$; (d) A15 phase in $\mathrm{Al}_{20} \mathrm{Ti}_{5} \mathrm{Mo}_{25} \mathrm{Nb}_{25} \mathrm{~V}_{25}$; (e) B2 phase in $\mathrm{Al}_{20} \mathrm{Ti}_{20} \mathrm{Mo}_{20} \mathrm{Nb}_{20} \mathrm{~V}_{20}$; $(f)$ B2\#2 phase in $\mathrm{Al}_{20} \mathrm{Ti}_{20} \mathrm{Mo}_{20} \mathrm{Nb}_{20} \mathrm{~V}_{20}$.

Table II. Empirical Parameters Values of the Investigated Alloys

\begin{tabular}{lcccr}
\hline Alloy & $\Delta S_{\text {mix }}(\mathrm{kJ} / \mathrm{mol})$ & $\delta(\mathrm{pct})$ & VEC & $\Delta H_{\text {mix }}(\mathrm{kJ} / \mathrm{mol})$ \\
\hline $\mathrm{Ti}_{25} \mathrm{Mo}_{25} \mathrm{Nb}_{25} \mathrm{~V}_{25}$ & 11.52 & 4.08 & 5 & -2.5 \\
$\mathrm{Al}_{15} \mathrm{Ti}_{10} \mathrm{Mo}_{25} \mathrm{Nb}_{25} \mathrm{~V}_{25}$ & 12.92 & 3.75 & 4.85 & -9.72 \\
$\mathrm{Al}_{20} \mathrm{Ti}_{5} \mathrm{Mo}_{25} \mathrm{Nb}_{25} \mathrm{~V}_{25}$ & 12.56 & 3.63 & 4.8 & -10.94 \\
$\mathrm{Al}_{20} \mathrm{Ti}_{20} \mathrm{Mo}_{20} \mathrm{Nb}_{20} \mathrm{~V}_{20}$ & 13.38 & 3.8 & 4.6 & -26 \\
$\mathrm{Al}_{15} \mathrm{Ti}_{25} \mathrm{Mo}_{20} \mathrm{Nb}_{20} \mathrm{~V}_{20}$ & 13.27 & 3.88 & 4.65 & 2.57 \\
$\mathrm{Al}_{10} \mathrm{Ti}_{30} \mathrm{Mo}_{20} \mathrm{Nb}_{20} \mathrm{~V}_{20}$ & 12.94 & 3.97 & 4.7 & 2.26 \\
\hline
\end{tabular}



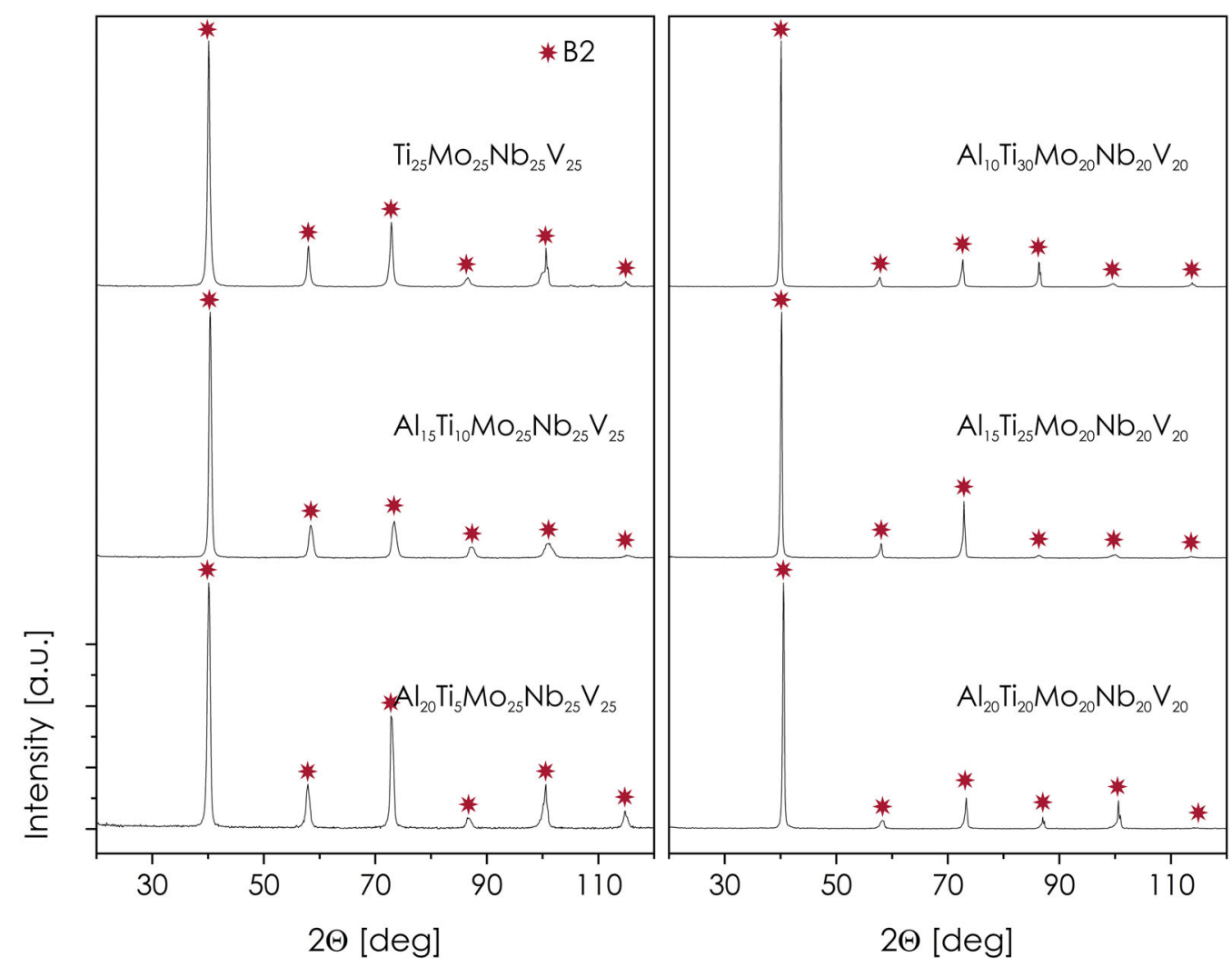

Fig. 3-XRD diffractograms of the as-cast alloys.

Table III. B2 Lattice Parameters of the Investigated Alloys, Determined by the Riley-Nelson Method

\begin{tabular}{lc}
\hline Alloy & Lattice Parameter $(\AA)( \pm 0.0005)$ \\
\hline $\mathrm{Ti}_{25} \mathrm{Mo}_{25} \mathrm{Nb}_{25} \mathrm{~V}_{25}$ & 3.183 \\
$\mathrm{Al}_{15} \mathrm{Ti}_{10} \mathrm{Mo}_{25} \mathrm{Nb}_{25} \mathrm{~V}_{25}$ & 3.200 \\
$\mathrm{Al}_{20} \mathrm{Ti}_{5} \mathrm{Mo}_{25} \mathrm{Nb}_{25} \mathrm{~V}_{25}$ & 3.151 \\
$\mathrm{Al}_{10} \mathrm{Ti}_{30} \mathrm{Mo}_{20} \mathrm{Nb}_{20} \mathrm{~V}_{20}$ & 3.192 \\
$\mathrm{Al}_{15} \mathrm{Ti}_{25} \mathrm{Mo}_{20} \mathrm{Nb}_{20} \mathrm{~V}_{20}$ & 3.188 \\
$\mathrm{Al}_{30} \mathrm{Ti}_{10} \mathrm{Mo}_{20} \mathrm{Nb}_{20} \mathrm{~V}_{20}$ & 3.184 \\
\hline
\end{tabular}

from 10 to $120 \mu \mathrm{m}$ for the $\mathrm{Ti}_{25} \mathrm{Mo}_{25} \mathrm{Nb}_{25} \mathrm{~V}_{25}$ alloy up to 50 to $200 \mu \mathrm{m}$ for the $\mathrm{Al}_{20} \mathrm{Ti}_{5} \mathrm{Mo}_{25} \mathrm{Nb}_{25} \mathrm{~V}_{25}$ composition. In the case of $\mathrm{Mo}_{25} \mathrm{Nb}_{25} \mathrm{~V}_{25}$-based series (Figures 4(d) to (f)), the grain sizes are clearly bigger, and are increasing with Al content, up to 100 to $900 \mu \mathrm{m}$ range for the $\mathrm{Al}_{20} \mathrm{Ti}_{20} \mathrm{Mo}_{20} \mathrm{Nb}_{20} \mathrm{~V}_{20}$. Basing on these results, it can be said that aluminum plays a decisive role in terms of the alloys microstructure in this system.

The results of SEM + EDS analysis is presented in Figure 5, with the measured average compositions being summarized in Table IV.

As one can see, in all cases (Figures 5(a) to (f)) the distribution of the elements is homogenous, supporting the XRD results, with the average compositions being close to the nominal ones. Furthermore, the observed microstructures are in a good agreement with the predictions of the thermodynamic modeling presented in Figure 1, proving the predicting capabilities of the
TCHEA 4 database. Nevertheless, it should be remembered that the presented results refer to the as-cast materials, and the homogenization process may further affect the observed microstructures. Also, one has to consider the sensitivity of the experimental methods in the case of the minority phases. Basing on the limitations of the EDS and XRD methods, the presence of small volumetric fractions of secondary phase precipitates (ca. 1 pct) cannot be unambiguously excluded, even though it is highly unlikely.

\section{Mechanical Performance}

Hardness tests were performed on all considered alloys. The results are presented in Figure 6.

For the alloys from the $\mathrm{Mo}_{25} \mathrm{Nb}_{25} \mathrm{~V}_{25}$-based series, the hardness increases with the growing $\mathrm{Al} /$ decreasing $\mathrm{Ti}$ content. The lowest value was obtained for the $\mathrm{Ti}_{25} \mathrm{Mo}_{25} \mathrm{Nb}_{25} \mathrm{~V}_{25}$ material (435 HV) while a maximum hardness of $545 \mathrm{HV}$ was determined for the $\mathrm{Al}_{20} \mathrm{Ti}_{5-}$ $\mathrm{Mo}_{25} \mathrm{Nb}_{25} \mathrm{~V}_{25}$ composition. For the second, $\mathrm{Mo}_{20} \mathrm{~N}$ $\mathrm{b}_{20} \mathrm{~V}_{20}$-based group of alloys, a similar trend is observed with the maximum hardness value measured for the $\mathrm{Al}_{20} \mathrm{Ti}_{20} \mathrm{Mo}_{20} \mathrm{Nb}_{20} \mathrm{~V}_{20}$ equimolar alloy-545 $\mathrm{HV}$, and minimum value of $460 \mathrm{HV}$ determined for the $\mathrm{Al}_{10} \mathrm{Ti}_{30}$ $\mathrm{Mo}_{20} \mathrm{Nb}_{20} \mathrm{~V}_{20}$ material. It is worth noting that despite the relatively big differences in elemental composition of other elements, both alloys containing 20 at. pct of Al are characterized by identical performance, further proving the importance of this particular element, which agrees well with the observations of Chen et al. ${ }^{[23]}$ 

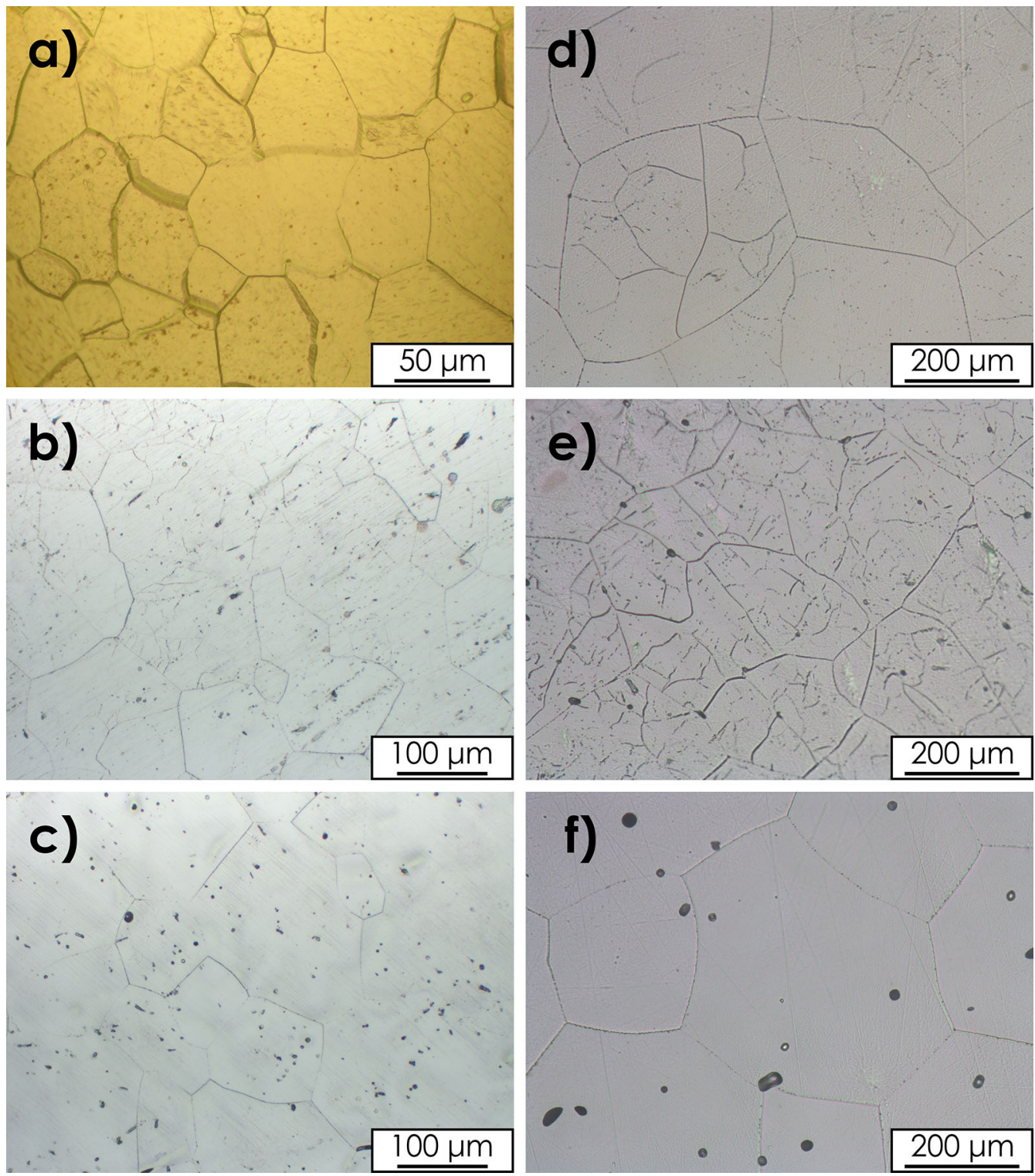

Fig. 4-Results of the optical observations for the investigated, as-cast alloys: (a) $\mathrm{Ti}_{25} \mathrm{Mo}_{25} \mathrm{Nb}_{25} \mathrm{~V}_{25} ;$ (b) $\mathrm{Al}_{15} \mathrm{Ti}_{10} \mathrm{Mo}_{25} \mathrm{Nb}_{25} \mathrm{~V}_{25} ;$ (c) $\mathrm{Al}_{20} \mathrm{Ti}_{5} \mathrm{Mo}_{25} \mathrm{Nb}_{25} \mathrm{~V}_{25}$; (d) $\mathrm{Al}_{10} \mathrm{Ti}_{30} \mathrm{Mo}_{20} \mathrm{Nb}_{20} \mathrm{~V}_{20}$; (e) $\mathrm{Al}_{15} \mathrm{Ti}_{25} \mathrm{Mo}_{20} \mathrm{Nb}_{20} \mathrm{~V}_{20} ;$ (f) $\mathrm{Al}_{20} \mathrm{Ti}_{20} \mathrm{Mo}_{20} \mathrm{Nb}_{20} \mathrm{~V}_{20}$.

Furthermore, it should be mentioned that except for the $\mathrm{Ti}_{25} \mathrm{Mo}_{25} \mathrm{Nb}_{25} \mathrm{~V}_{25}$ alloy, all reported hardness values are higher than for the commercial Inconel 718 alloy $(450 \mathrm{HV})$, and that the values for $\mathrm{Ti}_{25} \mathrm{Mo}_{25} \mathrm{Nb}_{25} \mathrm{~V}_{25}$ $(435 \mathrm{HV})$ and $\mathrm{Al}_{20} \mathrm{Ti}_{20} \mathrm{Mo}_{20} \mathrm{Nb}_{20} \mathrm{~V}_{20}(545 \mathrm{HV})$ are in excellent agreement with the available literature data (441 and $537 \mathrm{HV}$, respectively), ${ }^{[23]}$ proving the correctness of the applied methodology.

As mentioned in the introduction, one of the main challenges in the design of refractory high entropy alloys is their usually poor low-temperature ductility. Two alloys were selected for further studies: $\mathrm{Al}_{20} \mathrm{Ti}_{5-}$ $\mathrm{Mo}_{25} \mathrm{Nb}_{25} \mathrm{~V}_{25}$, in which $\mathrm{Al}$ is the main element decreasing the $V E C$ value of the alloy, and $\mathrm{Al}_{10} \mathrm{Ti}_{30} \mathrm{Mo}_{20} \mathrm{Nb}_{20} \mathrm{~V}_{20}$, in which Ti acted as the main plasticizer $\left(\mathrm{VEC}_{\mathrm{Ti}}=4\right)$, more in-line with the original postulates by Sheikh et al. ${ }^{[15]}$ As a result, the effectiveness of both elements in this role was investigated, which is of high significance, considering the crucial importance of aluminum presence in terms of the high-temperature resistance. In this context, the $\mathrm{Al}_{20} \mathrm{Ti}_{5-}$ $\mathrm{Mo}_{25} \mathrm{Nb}_{25} \mathrm{~V}_{25}$ appears to be the most promising composition, with relatively high $\mathrm{Al}$ content, combined with the low activity of $\mathrm{Ti}$, oxide phase which may be competitive to $\mathrm{Al}_{2} \mathrm{O}_{3}$ in terms of stability. The exemplary measured stress-strain curves are presented in Figure 7, with the mechanical properties being summarized in Table $\mathrm{V}$.

In both studied cases, the stress-strain curves (Figures 7(a) and (b)) indicate a ductile behavior of the materials (Figures 7(c) and (d)). For the first alloy, $\mathrm{Al}_{20} \mathrm{Ti}_{5} \mathrm{Mo}_{25} \mathrm{Nb}_{25} \mathrm{~V}_{25}$, despite the relatively high content of $\mathrm{Al}$, and low content of the assumed plasticizer (Ti), the average fracture strain $\varepsilon_{\mathrm{f}}$ reaches the value of 


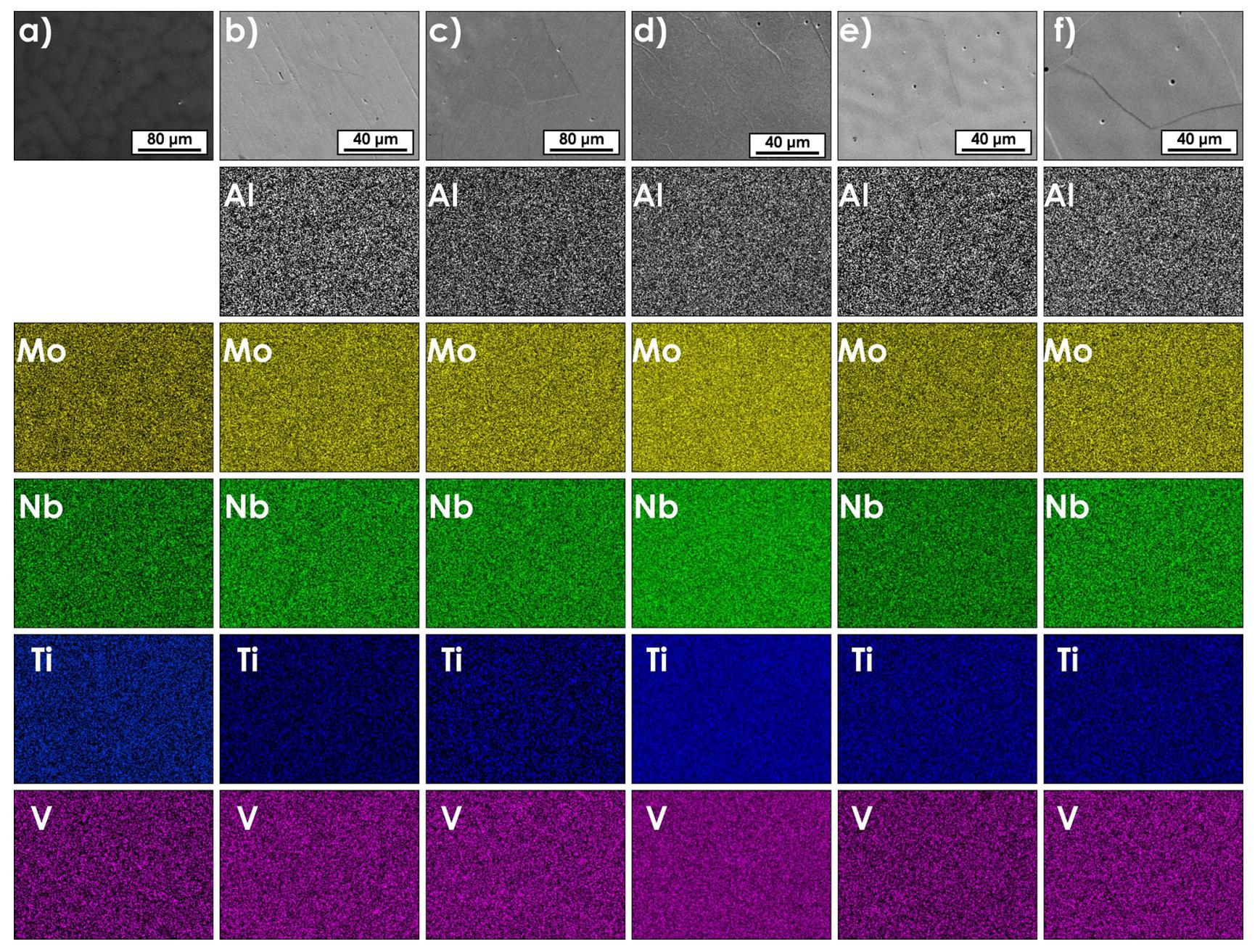

Fig. 5-Results of EDS mapping of the investigated RF HEAs alloys: (a) $\mathrm{Ti}_{25} \mathrm{Mo}_{25} \mathrm{Nb}_{25} \mathrm{~V}_{25} ;$ (b) $\mathrm{Al}_{15} \mathrm{Ti}_{10} \mathrm{Mo}_{25} \mathrm{Nb}_{25} \mathrm{~V}_{25} ;(c) \mathrm{Al}_{20} \mathrm{Ti}_{5} \mathrm{Mo}_{25} \mathrm{Nb}_{25} \mathrm{~V}_{25}$; (d) $\mathrm{Al}_{10} \mathrm{Ti}_{30} \mathrm{Mo}_{20} \mathrm{Nb}_{20} \mathrm{~V}_{20}$; (e) $\mathrm{Al}_{15} \mathrm{Ti}_{25} \mathrm{Mo}_{20} \mathrm{Nb}_{20} \mathrm{~V}_{20}$; (f) $\mathrm{Al}_{20} \mathrm{Ti}_{20} \mathrm{Mo}_{20} \mathrm{Nb}_{20} \mathrm{~V}_{20}$.

Table IV. Average Composition as Determined by EDS

\begin{tabular}{|c|c|c|c|c|c|}
\hline \multirow[b]{2}{*}{ Alloy } & \multicolumn{5}{|c|}{ Concentration (At. Pct) } \\
\hline & $\mathrm{Al}$ & $\mathrm{Ti}$ & Mo & $\mathrm{Nb}$ & $\mathrm{V}$ \\
\hline $\mathrm{Ti}_{25} \mathrm{Mo}_{25} \mathrm{Nb}_{25} \mathrm{~V}_{25}$ & - & $24.2(5)$ & $25.2(9)$ & $26.4(9)$ & $24.3(5)$ \\
\hline $\mathrm{Al}_{15} \mathrm{Ti}_{10} \mathrm{Mo}_{25} \mathrm{Nb}_{25} \mathrm{~V}_{25}$ & $13.8(3)$ & $11.6(4)$ & $24.2(9)$ & $23.9(9)$ & $24.0(5)$ \\
\hline $\mathrm{Al}_{20} \mathrm{Ti}_{5} \mathrm{Mo}_{25} \mathrm{Nb}_{25} \mathrm{~V}_{25}$ & $19.8(3)$ & $5.7(3)$ & $26.5(5)$ & $24.1(7)$ & $23.9(4)$ \\
\hline $\mathrm{Al}_{10} \mathrm{Ti}_{30} \mathrm{Mo}_{20} \mathrm{Nb}_{20} \mathrm{~V}_{20}$ & $11.6(3)$ & $28.9(4)$ & $19.5(5)$ & $19.2(6)$ & 20.7 (4) \\
\hline $\mathrm{Al}_{15} \mathrm{Ti}_{25} \mathrm{Mo}_{20} \mathrm{Nb}_{20} \mathrm{~V}_{20}$ & $15.1(3)$ & $26.0(3)$ & $19.3(5)$ & $21.8(7)$ & $20.8(4)$ \\
\hline $\mathrm{Al}_{20} \mathrm{Ti}_{20} \mathrm{Mo}_{20} \mathrm{Nb}_{20} \mathrm{~V}_{20}$ & $18.9(3)$ & $19.6(4)$ & $22.6(4)$ & $21.1(6)$ & 19.9 (4) \\
\hline
\end{tabular}

13.38 pct, with the ultimate strain $\varepsilon_{\mathrm{u}}$ value of 9.17 pct. This compares favorably to the equimolar AlMoNbTiV alloy with the same Al content, for which 2.5 pct value was reported, ${ }^{[23]}$ not to mention the vast majority of the RF HEAs, for which a brittle behavior is reported. ${ }^{[14]}$ On the other hand, the yield strength $\sigma_{\mathrm{y}}$ appears to be relatively low, with an average value of $873 \mathrm{MPa}$, compared to $1375 \mathrm{MPa}$ for AlMoNbTiV. ${ }^{[23]}$ The obtained results are especially interesting in the light of the results for $\mathrm{Al}_{10} \mathrm{Ti}_{30} \mathrm{Mo}_{20} \mathrm{Nb}_{20} \mathrm{~V}_{20}$, for which very similar values of $\varepsilon_{\mathrm{f}}$ and $\varepsilon_{\mathrm{u}}$, of 13.25 and 9.00 pct, respectively, were obtained, despite the much higher content of Ti plasticizer. At the same time, this alloy was characterized by a noticeably higher yield strength of $1502 \mathrm{MPa}$ which is relatively high for reported single-phase refractory HEAs. ${ }^{[14]}$ Based on the results, it appears that the effectiveness of $\mathrm{Al}$ as the potential plasticizer may have been overlooked, or, alternatively, 
the complexity of synergistic effects, responsible for the observed ductility, may have been underestimated in previous studies. $[14,23]$

\section{CONCLUSIONS}

In the presented study, two series of the refractory high entropy alloys (RF HEA) from Al-Mo-Nb-Ti-V system: $\quad \mathrm{Al}_{20-x} \mathrm{Ti}_{x} \mathrm{Mo}_{25} \mathrm{Nb}_{25} \mathrm{~V}_{25}$ and $\mathrm{Al}_{20-x} \mathrm{Ti}_{x-}$ $\mathrm{Mo}_{20} \mathrm{Nb}_{20} \mathrm{~V}_{20}$, were successfully produced by arc-melting technique. The thermodynamic modeling indicates

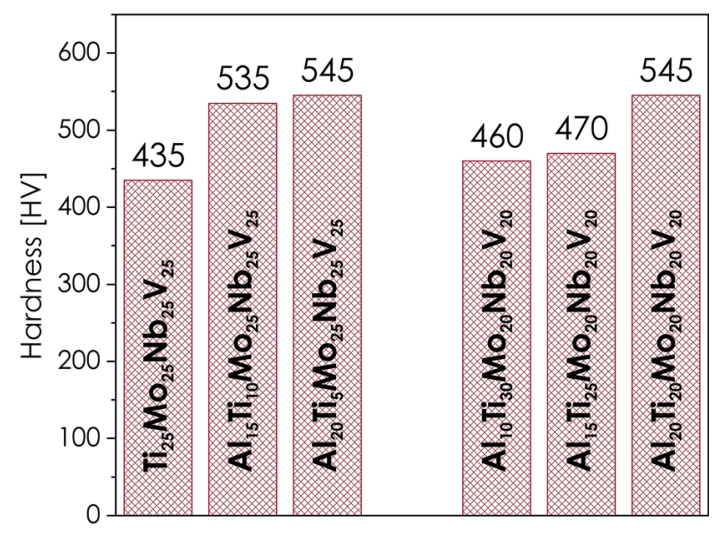

Fig. 6-Vickers hardness of the investigated refractory high entropy alloys. the presence of a single-phase, B2 structure in all considered as-cast alloys, with the $\mathrm{Mo}_{25} \mathrm{Nb}_{25} \mathrm{~V}_{25}$-based series being characterized by the tendency toward the formation of Mo-rich A15 phase, while the precipitation of the secondary, Ti-rich B2 phase is predicted for $\mathrm{Al}_{20} \mathrm{Ti}_{20} \mathrm{Mo}_{20} \mathrm{Nb}_{20} \mathrm{~V}_{20}$. Curiously enough, despite the similarities to Mo and $\mathrm{Nb}$ in terms of the binary phase diagrams with other elements, vanadium appears to be expelled from the low-temperature A15 and B2\#2 phases, at the same time appearing to be the strongest stabilizer of the main $\mathrm{B} 2$ phase. The experimental results further support the correctness of thermodynamic predictions, with all the alloys being characterized by the single-phase, body-centered cubic structure with homogenous distribution of all elements in the as-cast state. The microstructure analysis suggests the decisive role of $\mathrm{Al}$ in terms of the grain size, with the tendency toward larger grain size being observed for Al-rich alloys from both studied groups. The increasing Al content can be also correlated with hardness growing value, reaching the maximum of $545 \mathrm{HV}$ for $\mathrm{Al}_{20} \mathrm{Ti}_{20}$ $\mathrm{Mo}_{20} \mathrm{Nb}_{20} \mathrm{~V}_{20}$ and $\mathrm{Al}_{20} \mathrm{Ti}_{5} \mathrm{Mo}_{25} \mathrm{Nb}_{25} \mathrm{~V}_{25}$ compositions. Basing on the measured stress-strain curves for the selected $\mathrm{Al}_{20} \mathrm{Ti}_{5} \mathrm{Mo}_{25} \mathrm{Nb}_{25} \mathrm{~V}_{25}$ and $\mathrm{Al}_{10} \mathrm{Ti}_{30} \mathrm{Mo}_{20} \mathrm{Nb}_{20}$ $\mathrm{V}_{20}$, the studied alloys possess ductile behavior, a highly coveted feature for refractory HEAs. The obtained values of ultimate strain (9.17 and 9.00 pct, respectively), and fracture strain (13.38 and 13.25 pct, respectively) compare favorably to the available literature

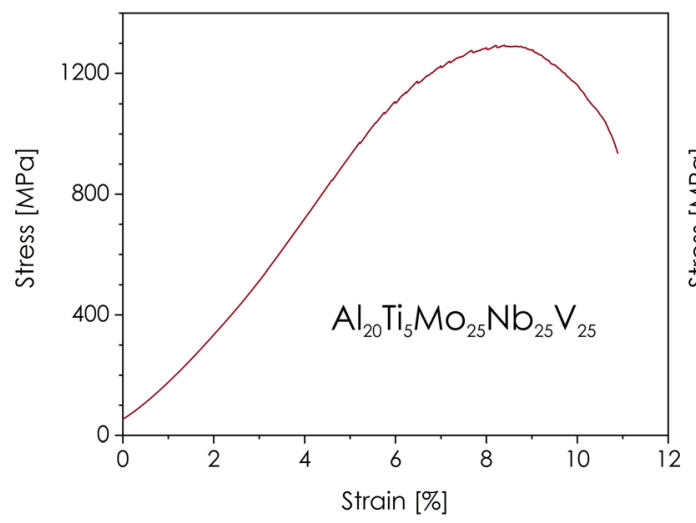

(a)

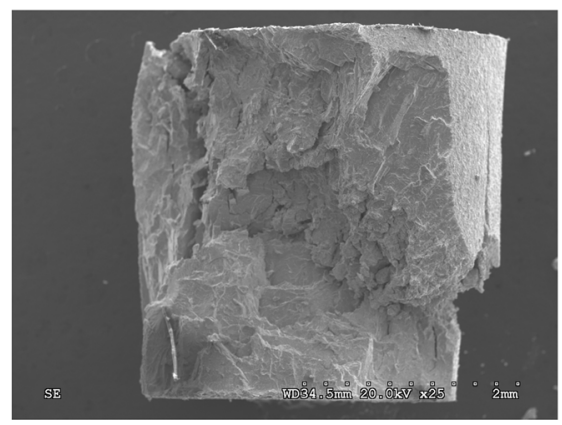

(c)

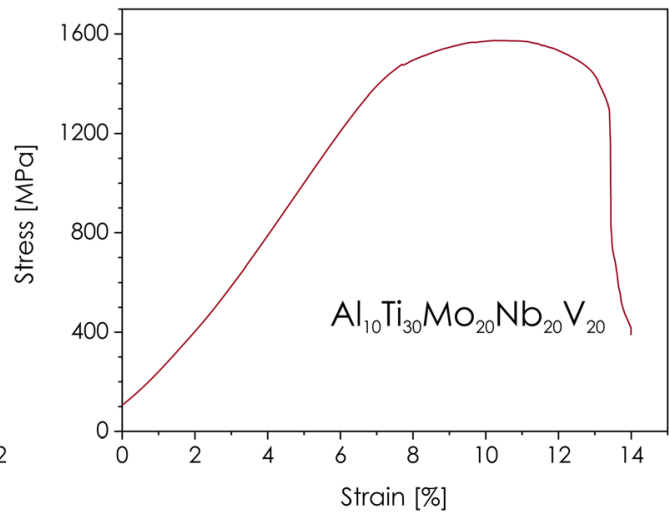

(b)

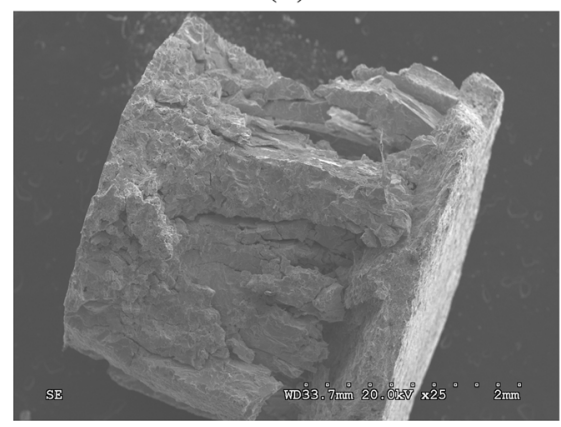

(d)

Fig. 7-Exemplary compression stress-strain curves of the RF HEA: (a) $\mathrm{Al}_{20} \mathrm{Ti}_{5} \mathrm{Mo}_{25} \mathrm{Nb}_{25} \mathrm{~V}_{25} ;$ (b) $\mathrm{Al}_{10} \mathrm{Ti}_{30} \mathrm{Mo}_{20} \mathrm{Nb}_{20} \mathrm{~V}_{20}$; fracture micrograph: (c) $\mathrm{Al}_{20} \mathrm{Ti}_{5} \mathrm{Mo}_{25} \mathrm{Nb}_{25} \mathrm{~V}_{25} ;$ (d) $\mathrm{Al}_{10} \mathrm{Ti}_{30} \mathrm{Mo}_{20} \mathrm{Nb}_{20} \mathrm{~V}_{20}$. 
Table V. Average Values of Mechanical Parameters for Tested Materials: Young's Modulus E, Yield Strength $\sigma_{\mathbf{y}}$, Ultimate Strength $\sigma_{\mathrm{u}}$, Ultimate Strain $\varepsilon_{\mathrm{u}}$, and Fracture Strain $\varepsilon_{\mathrm{f}}$

\begin{tabular}{lcccr}
\hline Alloy & $E(\mathrm{GPa})$ & $\sigma_{\mathrm{y}}(\mathrm{MPa})$ & $\sigma_{\mathrm{u}}(\mathrm{MPa})$ & $\varepsilon_{\mathrm{u}}(\mathrm{Pct})$ \\
\hline $\mathrm{Al}_{20} \mathrm{Ti}_{5} \mathrm{Mo}_{25} \mathrm{Nb}_{25} \mathrm{~V}_{25}$ & 13.7 & 873 & 1033.6 & 9.17 \\
$\mathrm{Al}_{10} \mathrm{Ti}_{30} \mathrm{Mo}_{20} \mathrm{Nb}_{20} \mathrm{~V}_{20}$ & 19.6 & 1502 & 1548.8 & $\varepsilon_{\mathrm{f}}(\mathrm{Pct})$ \\
\hline
\end{tabular}

data. The similarity between both investigated alloys is extremely encouraging, proving that the prominent $\mathrm{Al}$ content may not be necessarily deleterious in terms of ductility. Consequently, it may be possible to design refractory HEAs, with the inherent ability to form protective alumina scales at high temperatures, without compromising their low-temperature ductility. However, based on the literature data, the corrosion behavior of RF HEAs appears to be highly complex, therefore despite the content of Al at the level typically accepted as sufficient to support the selective oxidation process, further studies must proceed in order to verify this capability in the presented materials. Such investigations are being currently carried out and will be a subject of a separate paper. Still, regardless of their results, the presented data can be considered a promising starting point for the further development of ductile and corrosion resistant RF HEAs.

\section{ACKNOWLEDGMENTS}

Financial support of National Science Centre under Projects No. 2018/02/X/ST8/02397 is acknowledged.

\section{CONFLICT OF INTEREST}

On behalf of all authors, the corresponding author states that there is no conflict of interest.

\section{OPEN ACCESS}

This article is licensed under a Creative Commons Attribution 4.0 International License, which permits use, sharing, adaptation, distribution and reproduction in any medium or format, as long as you give appropriate credit to the original author(s) and the source, provide a link to the Creative Commons licence, and indicate if changes were made. The images or other third party material in this article are included in the article's Creative Commons licence, unless indicated otherwise in a credit line to the material. If material is not included in the article's Creative Commons licence and your intended use is not permitted by statutory regulation or exceeds the permitted use, you will need to obtain permission directly from the copyright holder. To view a copy of this licence, visit http://creat ivecommons.org/licenses/by/4.0/.

\section{REFERENCES}

1. K.H. Huang, J.W. Yeh: A Study on Multicomponent Alloy Systems Containing Equal-mole Elements, M.S. thesis, National Tsing Hua University, Hsinchu, 1996.

2. JW Yeh, SK Chen, SJ Lin, JY Gan, and TS Chin: Adv. Eng. Mater., 2004, vol. 6, pp. 299-303.

3. B Cantor, IT Chang, P Knight, and AJ Vincent: Mater. Sci. Eng. A, 2004, vols. 375-377, pp. 213-18.

4. LS Zhang, GL Ma, LC Fu, and JY Tian: $A M R$, 2013, vols. 631-632, pp. 227-32.

5. DB Miracle and ON Senkov: Acta Mater., 2017, vol. 122, pp. $448-511$.

6. EJ Pickering and NG Jones: InterMater. Rev., 2016, vol. 61 (3), pp. 183-202.

7. DB Miracle, JD Miller, ON Senkov, C Woodward, MD Uchic, and J Tiley: Entropy, 2014, vol. 16, pp. 494-525.

8. XQ Wang, Y Ma, B Jiang, X Li, Y Shi, C Dong, and PK Liaw: Scri Mater, 2010, vol. 120, pp. 85-89.

9. Y Zhang, TT Zuo, Z Tang, MC Gao, KA Dahmen, PK Liaw, and ZP Lu: Prog. Mater. Sci., 2014, vol. 61, pp. 1-93.

10. ON Senkov, GB Wilks, DB Miracle, CP Chuang, and PK Liaw: Intermetallics, 2010, vol. 18, pp. 1758-65.

11. ON Senkov, DB Miracle, KJ Chaput, and K and J.P. Cousine, : J. of MatRes., 2018, vol. 33, pp. 3092-128.

12. ON Senkov, OD Isheim, D Seidman, and A Pilchak: Entropy, 2018, vol. 18 (3), p. 102.

13. ON Senkov, GB Wilks, JM Scott, and DB Miracle: Intermetallics, 2011, vol. 19, pp. 698-706.

14. ON Senkov, D Isheim, DN Seidman, and AL Pilchak: Entropy, 2016, vol. 18, p. 102.

15. S Sheikh, S Shafeie, Q Hu, J Ahlstrom, C Persson, J Vesely, J Zyka, U Klement, and S Guo: J. Appl. Phys., 2016, vol. 120, p. 164902.

16. S Guo, C Ng, J Lu, and CT Liu: J. Appl. Phys., 2011, vol. 109, p. 103505.

17. ON Senkov, JM Scott, SV Senkova, DB Miracle, and CF Woodward: Jallcom, 2011, vol. 509, pp. 6043-48.

18. B Gorr, S Schellert, F Müller, HJ Christ, A Kauffmann, and M Heilmaier: Adv. Eng. Mater., 2021, vol. 25, p. 2001047.

19. R.A. Robie, B.S. Hemingway, and J.R. Fisher: United States Government Printing Office, Washington, 1978.

20. B Gorr, F Müller, S Schellert, HJ Christ, H Chen, A Kauffmann, and M Heilmaier: Corr. Sci., 2020, vol. 166, p. 108475.

21. Thermo-Calc Software TCHEA4 High Entropy Alloys database (accessed 23 January 2021).

22. MH Tsai and JW Yeh: Mater. Res. Lett., 2014, vol. 2 (3), pp. $107-23$.

23. SY Chen, X Yang, KA Dahmen, PK Liaw, and Y Zhang: Entropy, 2014, vol. 16 (2), pp. 870-84.

Publisher's Note Springer Nature remains neutral with regard to jurisdictional claims in published maps and institutional affiliations. 